\title{
PENGARUH PENAMBAHAN KONSENTRASI EKSTRAK TEH HIJAU TERHADAP MUTU ES KRIM BENGKUANG (Pacharryzus erosus, L)
}

\author{
Sahadi Didi Ismanto, Aisman, dan Carmelita Puteri Reyadha \\ Jurusan Teknologi Hasil Pertanian, Fakultas Teknologi Pertanian, Universitas Andalas, Padang, 25163 \\ Email: sahadididiismanto@ae.unand.ac.id
}

\begin{abstract}
ABSTRAK
Penelitian ini bertujuan untuk mengetahui pengaruh konsentrasi penambahan ekstrak teh hijau terhadap mutu es krim bengkuang dan mengetahui mutu es krim bengkuang yang dihasilkan. Penelitian ini telah dilaksanakan di Laboraturium Jurusan Teknologi Hasil Pertanian, Fakultas Teknologi Pertanian Universitas Andalas. Penelitian ini menggunakan Rancangan Acak Lengkap (RAL) dengan 5 perlakuan dan 3 ulangan. Kemudian jika berbeda nyata, dilanjutkan dengan uji Duncan's New Multiple Range Test (DNMRT) pada taraf nyata 5\%. Perlakuan penelitian ini adalah penambahan ekstrak teh hijau dengan berbagai konsentrasi $(A=5 \%, B=7,5 \%, C=10 \%, D=12,5 \%, E=15 \%)$. Hasil penelitian menujukkan bahwa penambahan ekstrak teh hijau terhadap es krim bengkuang memberikan pengaruh yang tidak berbeda nyata terhadap kadar gula, total padatan terlarut, overrun dan daya leleh. Namun berbeda sangat nyata terhadap kadar protein, kadar lemak dan aktivitas antioksidannya. Hasil uji organoleptik menunjukkan bahwa perlakuan Penambahan Ekstrak Teh Hijau Konsentrasi 5\% adalah produk terbaik yang dapat diterima oleh panelis dengan persentase rasa $55 \%$, aroma $40 \%$, warna $45 \%$ dan tekstur $40 \%$. Karakteristik dari perlakuan A adalah kadar gula 9,17\%, kadar protein 8,32\%, kadar lemak $8,36 \%$, kadar padatan terlarut $16,29 \%$, aktivitas antioksidan $35,38 \%$, overrun $27,38 \%$, daya leleh 5,9 menit.

Kata kunci-bengkuang; esktrak teh hijau; es krim
\end{abstract}

\section{PENDAHULUAN}

Bengkuang merupakan tanaman umbi akar dengan daging buah berwarna putih dan kulit kecoklatan. Berdasarkan Dinas Pertanian Kota Padang - Statistik Kecamatan Pauh (2012), potensi bengkuang yang dimiliki cukup besar dengan luas lahan panen 96 ha dan jumlah produksi mencapai 2.996 ton pada tahun 2011. Jumlah produksi bengkuang terus meningkat tiap tahunnya, pada tahun 2009 produksi bengkuang mencapai 2.208 ton dan pada tahun 2010 produksi mencapai 2.419 ton. Melihat jumlah bengkuang yang begitu banyak hendaknya dapat dimanfaatkan dengan baik sehingga dapat meningkatkan perekonomian petani bengkuang. Konsumen pada umumnya kurang tertarik dengan bengkuang karena tidak ada produk olahannya yang dapat menarik minat konsumen. Dengan demikian, harga jual bengkuang masih sangat rendah. Melihat hal ini, inovasi baru yang lebih menarik konsumen diperlukan untuk meningkatkan harga jual bengkuang. Selain itu, umur simpan bengkuang yang terbatas juga menjadi kendala dalam pengolahannya. Menurut Anonymous (2009), penyimpanan bengkuang yang terlalu lama menyebabkan umbinya berserat. Oleh karena itu perlu dilakukan pengolahan umbi bengkuang.

Cukup banyak potensi olahan bengkuang yang dapat dilakukan dalam bidang kuliner, salah satu contohnya adalah es krim. Bengkuang tidak memiliki warna yang khas serta memiliki aroma sedikit langu sehingga terkadang kurang disukai oleh panelis, oleh karena itu demi memperbaiki mutu es krim bengkuang pada penelitian ini diberikan tambahan ekstrak teh hijau untuk memberikan aroma dan warna pada es krim bengkuang tersebut. Selain itu, teh hijau merupakan tanaman bahan penyegar yang baik dikonsumsi. Teh hijau merupakan teh yang masih tinggi kandungan antioksidannya. Antioksidan dinyatakan sebagai substansi yang menghambat proses oksidasi. Antioksidan memiliki kemampuan dalam memberikan elektron, mengikat dan mengakhiri reaksi berantai radikal bebas yang mematikan (Rohdiana, 2009).

Penambahkan ekstrak teh hijau pada pembuatan es krim bengkuang ini, diharapkan mampu menganekaragamkan pangan lokal dan menaikkan harga jual dan mutu hasil tanaman lokal itu sendiri melalui pengolahan yang dilakukan. Tujuan dari penelitian ini adalah mengetahui pengaruh konsentrasi ekstrak teh hijau yang ditambahkan terhadap mutu es krim bengkuang. 


\section{METODOLOGI PENELITIAN}

\section{A. Bahan dan Alat}

Bahan-bahan yang digunakan dalam penelitian ini adalah umbi, teh hijau dengan merek dagang "Kepala Djenggot", gula, CMC, susu sapi segar, telur ayam dan air. Sedangkan untuk analisa kimia

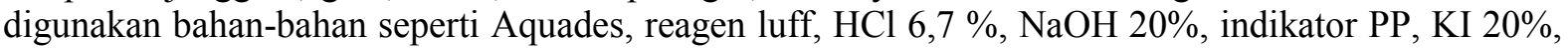
$\mathrm{H}_{2} \mathrm{SO}_{4} 25 \%$, thio sulfat $0,1 \mathrm{~N}$, indikator amilum, $\mathrm{H}_{2} \mathrm{SO}_{4}$ pekat, batu didih, $\mathrm{NaOH} 50 \%$, asam borat, indikator MM, $\mathrm{HCl} 0,4381 \mathrm{~N}$, heksan, selenium mix, DPPH, metanol, dan buffer asetat $100 \mathrm{mM}(\mathrm{Ph}$ 5,5). Alat-alat yang digunakan adalah timbangan analitik, timbangan analitik, erlemeyer, gelas ukur, gelas piala, buret, kertas saring, corong gelas, labu Kjeldahl, spatula, labu lemak, soxhlet, pipet, desikator, dan lain-lain.

\section{B. Rancangan Percobaan}

Rancangan yang digunakan adalah Rancangan Acak Lengkap (RAL) dengan 5 perlakuan dan 3 ulangan. Kemudian jika berbeda nyata (F hitung $>$ F tabel), dilanjutkan dengan uji Ducan's New Multiple Rangetest (DNMRT) pada taraf nyata 5\%. Adapun formulasi pada pembuatan es krim bengkuang dengan penambahan ekstrak teh hijau ditampilkan dalam Tabel 1.

Tabel 1. Keperluan Bahan Adonan Es Krim

\begin{tabular}{lccccc}
\hline \multirow{2}{*}{ Bahan } & \multicolumn{5}{c}{ Perlakuan (g) } \\
\cline { 2 - 6 } & A & B & C & D & E \\
\hline Ekstrak Bengkuang & 65,02 & 65,02 & 65,02 & 65,02 & 65,02 \\
Gula & 25 & 25 & 25 & 25 & 25 \\
CMC & 2 & 2 & 2 & 2 & 2 \\
Susu Segar & 39,99 & 39,99 & 39,99 & 39,99 & 39,99 \\
Telur & 14,99 & 14,99 & 14,99 & 14,99 & 14,99 \\
\hline Penambahan Ekstrak Teh & Konsentrasi & Konsentrasi & Konsentrasi & Konsentrasi & Konsentrasi \\
Hijau Sebanyak 15 g & $5 \%$ & $7,5 \%$ & $10 \%$ & $12,5 \%$ & $15 \%$ \\
\hline
\end{tabular}

\section{Pelaksanaan Penelitian}

1. Pengekstrakan Bengkuang

Diapkan bengkuang sebanyak yang dibutuhkan, dikupas dan dicuci hingga bersih kemudian diiris kecil-kecil. Setelah itu dilakukan pengekstrakan bengkuang menggunakan juicer untuk mendapatkan sarinya.

\section{Pengekstrakan Teh Hijau}

Timbang teh hijau sesuai perlakuan (A: Konsentrasi 5\%=5 g teh hijau $95 \mathrm{ml}$ air, B: Konsentrasi $7,5 \%=7,5 \mathrm{~g}$ teh hijau 92,5 $\mathrm{ml}$ air, C: Konsentrasi $10 \%=10 \mathrm{~g}$ teh hijau $90 \mathrm{ml}$ air, D: Konsentrasi $12,5 \%=$ $12,5 \mathrm{~g}$ teh hijau 87,5 air, E: Konsentrasi $15 \%=15 \mathrm{~g}$ teh hijau $85 \mathrm{ml}$ air). Blender kering teh hijau untuk memperluas permukaan. Seduh teh hijau dengan air suhu $70^{\circ} \mathrm{C}$ selama 10 menit. Lakukan penyaringan teh hijau untuk memisahkan ekstraknya.

\section{Pembuatan Es Krim Bengkuang Dengan Penambahan Berbagai Konsentrasi Ekstrak Teh Hijau (Modifikasi Fauziah, 2010)}

Susu sapi segar dipasteurisasi sampai suhu $75^{\circ} \mathrm{C}$ selama 10 menit kemudian dinginkan. Ambil sari bengkuang sebanyak 65,02 g kemudian campurkan susu segar 39,99 g, telur 14,99 g, CMC 2 g, dan gula $25 \mathrm{~g}$. Setelah itu tambahkan $15 \mathrm{~g}$ ekstrak teh hijau sesuai perlakuan. Homogenkan bahan menggunakan mixer selama 15 menit. Masukkan adonan tersebut ke dalam lemari pendingin (suhu $0^{0} \mathrm{C}$ ), setelah 3 jam penyimpanan, adonan dimixer kembali setelah itu disimpan kembali ke lemari pendingin. Setelah 3 jam kemudian lakukan hal yang sama kemudian bekukan es krim di dalam freezer.

\section{Pengamatan}

Pengamatan yang dilakukan terhadap es krim yaitu kadar sukrosa, kadar padatan terlarut, kadar protein, kadar lemak, penentuan aktivitas antioksidan, organoleptik, analisa harga pokok, overrun, dan daya leleh es krim. 


\section{HASIL DAN PEMBAHASAN}

\section{A. Kadar Gula}

Hasil Kadar gula pada setiap perlakuan tidak berbeda nyata dan angka yang diperoleh tidak berbeda jauh. Hal ini disebabkan karena persentase pemakaian gula pada setiap perlakuan sama. Kadar gula pada es krim bengkuang dengan penambahan ekstrak teh hijau dapat dilihat pada Tabel 2.

Tabel 2. Pengamatan Kadar Gula

\begin{tabular}{lc}
\hline \multicolumn{1}{c}{ Perlakuan } & Kadar Gula (\%) \\
\hline A ( Konsentrasi ekstrak teh hijau 5\% ) & 9,17 \\
B (Konsentrasi ekstrak teh hijau 7,5\% ) & 9,62 \\
C (Konsentrasi ekstrak teh hijau 10\% ) & 9,74 \\
D ( Konsentrasi ekstrak teh hijau 12,5\%) & 9,83 \\
E (Konsentrasi ekstrak teh hijau 15\% ) & 9,90 \\
\hline KK=9,83\% & \\
\hline
\end{tabular}

Dari hasil yang didapatkan (Tabel2), kadar gula es krim bengkuang ini sudah memenuhi standar SNI dengan kadar minimum $8 \%$ untuk es krim. Peningkatan kadar gula yang terjadi pada tiap perlakuan disebabkan karena teh hijau mengandung gula. Menurut Rossi (2010), kandungan gula dalam teh hijau sebesar $0,75 \%$, oleh karena itu semakin meningkat konsentrasi teh hijau yang ditambahkan maka semakin meningkat pula kadar gula es krim bengkuang yang dihasilkan.

\section{B. Kadar Protein}

Kadar protein es krim bengkuang mengalami kenaikan pada setiap perlakuannya. Kadar protein pada es krim bengkuang dengan penambahan ekstrak teh hijau dapat dilihat pada Tabel 3.

Tabel 3. Pengamatan Kadar Protein

\begin{tabular}{|c|c|}
\hline Perlakuan & Kadar Protein $(\%)$ \\
\hline A ( Konsentrasi ekstrak teh hijau 5\% ) & 8,32 a \\
\hline B ( Konsentrasi ekstrak teh hijau 7,5\%) & $8,40 \mathrm{ab}$ \\
\hline C ( Konsentrasi ekstrak teh hijau 10\% ) & $8,44 \quad b$ \\
\hline D ( Konsentrasi ekstrak teh hijau $12,5 \%$ ) & 8,46 \\
\hline E ( Konsentrasi ekstrak teh hijau $15 \%$ ) & 8,55 \\
\hline
\end{tabular}

Pada Tabel 3 terlihat, kadar protein tertinggi terdapat pada perlakuan E yaitu sebesar 8,55\%. Semakin tinggi konsentrasi ekstrak teh hijau yang ditambahkan pada es krim bengkuang maka semakin meningkat kadar protein yang dihasilkan. Hal ini disebabkan karena kadar protein dalam teh hijau cukup besar yaitu sekitar 29\%. Berdasarkan SNI 01-3713-1995 kadar minimum protein dalam es krim adalah $2,7 \%$. Dari data yang diperoleh, kadar protein es krim bengkuang sudah memenuhi standar tersebut.

\section{Kadar Lemak}

Lemak yang terdapat dalam es krim bengkuang diperoleh dari kuning telur dan susu segar. Persentase penambahan telur dan susu segar sama untuk setiap perlakuannya, akan tetapi hasil analisa kadar lemak menunjukkan penurunan pada setiap perlakuan. Kadar lemak pada es krim bengkuang dengan penambahan ekstrak teh hijau dapat dilihat pada Tabel 4.

Tabel 4. Pengamatan Kadar Lemak

\begin{tabular}{lc}
\hline \multicolumn{1}{c}{ Perlakuan } & Kadar Lemak (\%) \\
\hline E ( Konsentrasi ekstrak teh hijau 15\% ) & $3,11 \mathrm{a}$ \\
D ( Konsentrasi ekstrak teh hijau 12,5\%) & $4,74 \mathrm{~b}$ \\
C ( Konsentrasi ekstrak teh hijau 10\%) & $5,23 \mathrm{~b}$ \\
B (Konsentrasi ekstrak teh hijau 7,5\%) & $6,67 \mathrm{c}$ \\
A ( Konsentrasi ekstrak teh hijau 5\% ) & $8,36 \quad \mathrm{~d}$ \\
\hline
\end{tabular}

$\mathrm{KK}=5,33 \%$ 
Penurunan yang terjadi pada kadar lemak es krim bengkuang ini disebabkan karena teh hijau mengandung zat bioaktif berupa antioksidan yang dapat menurunkan kadar lemak pada bahan pangan (Muharlien, 2010). Dari data pada Tabel 4, dapat dilihat bahwa perlakuan D dan E tidak memenuhi SNI 01-3713-1995 es krim dimana kadar lemak minimumnya adalah 5\%. Perlakuan A, B dan C sudah memenuhi SNI dengan kadar lemak yang dihasilkan 5,23\%, 6,67\% dan 8,36\%. Semakin tinggi konsentrasi ekstrak teh hijau yang ditambahkan, maka semakin terjadi penurunan kadar lemak es krim bengkuang yang dihasilkan.

\section{Total Padatan Terlarut}

Total padatan terlarut menunjukkan jumlah bahan padatan yang dapat larut dalam air. Hal ini berbeda terhadap mutu es krim. Total padatan pada es krim bengkuang dengan penambahan ekstrak teh hijau dapat dilihat pada Tabel 5.

Tabel 5. Pengamatan Total Padatan Terlarut

\begin{tabular}{lc}
\hline \multicolumn{1}{c}{ Perlakuan } & Kadar Padatan Terlarut (\%) \\
\hline D ( Konsentrasi ekstrak teh hijau 12,5\% ) & 16,75 \\
B ( Konsentrasi ekstrak teh hijau 7,5\% ) & 16,57 \\
C ( Konsentrasi ekstrak teh hijau 10\% ) & 16,53 \\
E ( Konsentrasi ekstrak teh hijau 15\% ) & 16,45 \\
A ( Konsentrasi ekstrak teh hijau 5\% ) & 16,29 \\
\hline KK $=3,8 \%$
\end{tabular}

$\mathrm{KK}=3,8 \%$

Jumlah padatan terlarut menentukan daya leleh es krim. Semakin banyak padatan yang terkandung dalam bahan tersebut akan memberikan waktu leleh yang lebih lama terhadap es krim yang dihasilkan. Total kadar padatan terlarut semua perlakuan sudah memenuhi standar SNI dengan batasan minimum 3,4\%, dengan demikian dapat dikatakan total padatan dalam es krim bengkuang sudah cukup baik.

\section{E. Aktivitas Antioksidan}

Antioksidan berguna sebagai penangkal radikal bebas di dalam tubuh. Antioksidan yang didapatkan pada produk ini berasal dari teh hijau (Camellia sinensis). Teh hijau dipilih pada pembuatan produk ini karena teh hijau memiliki kandungan antioksidan yang paling tinggi dibandingkan dengan teh lainnya. Antioksidan yang terkandung pada teh hijau adalah katekin. Aktivitas antioksidan pada es krim bengkuang dengan penambahan ekstrak teh hijau dapat dilihat pada Tabel 6 .

Tabel 6. Pengamatan Aktivitas Antioksidan

\begin{tabular}{lc}
\hline \multicolumn{1}{c}{ Perlakuan } & Antioksidan (\%) \\
\hline A ( Konsentrasi ekstrak teh hijau 5\%) & $35,38 \mathrm{a}$ \\
B ( Konsentrasi ekstrak teh hijau 7,5\%) & $38,8 \mathrm{~b}$ \\
C ( Konsentrasi ekstrak teh hijau 10\%) & $44,44 \quad \mathrm{c}$ \\
D ( Konsentrasi ekstrak teh hijau 12,5\%) & $47,63 \quad \mathrm{~d}$ \\
E ( Konsentrasi ekstrak teh hijau 15\%) & $50,77 \quad \mathrm{e}$ \\
\hline KK=3,36\% & \\
\hline
\end{tabular}

Perlakuan A memiliki kandungan antioksidan yang paling rendah yaitu sebesar 35,38\% , sedangkan perlakuan E memiliki kandungan antioksidan yang paling tinggi yaitu sebesar $50,77 \%$. Hal ini dapat terjadi karena pada setiap perlakuan diberikan penambahan ekstrak teh hijau yang berbeda. Perlakuan A hanya diberikan penambahan ekstrak teh hijau konsentrasi 5\%, sedangkan perlakuan E diberikan penambahan ekstrak teh hijau konsentrasi 15\%. Dapat dikatakan semakin tinggi penambahan konsentrasi teh hijau, maka akan didapatkan kandungan antioksidan yang semakin tinggi pula.

\section{F. Overrun}

Overrun menentukan tingkat kesukaan panelis dari segi tekstur dan dapat menentukan daya leleh es krim. Semakin baik overrun es krim maka tekstur yang didapatkan semakin lembut. Hal ini dipertegas dengan penelitian yang telah dilakukan oleh Syafutri, 2012 yang mengatakan bahwa overrun 
mempengaruhi tekstur dan kepadatan yang sangat menentukan kualitas es krim. Overrun pada es krim bengkuang dengan penambahan ekstrak teh hijau dapat dilihat pada Tabel 7.

Tabel 7. Pengamatan Overrun

\begin{tabular}{lc}
\hline \multicolumn{1}{c}{ Perlakuan } & Overrun (\%) \\
\hline E ( Konsentrasi ekstrak teh hijau 15\% ) & 27,38 \\
A ( Konsentrasi ekstrak teh hijau 5\% ) & 27,38 \\
D ( Konsentrasi ekstrak teh hijau 12,5\%) & 27,09 \\
C ( Konsentrasi ekstrak teh hijau 10\%) & 27,09 \\
B ( Konsentrasi ekstrak teh hijau 7,5\%) & 27,09 \\
\hline KK=8,72\% & \\
\hline
\end{tabular}

Overrun didapatkan pada saat pengocokan bahan. Menurut Malaka (2011), Pengembangan volume (overrun) yaitu kenaikan volume es krim karena udara yang membusa ke dalam campuran selama proses pembuihan dan pembekuan. Menurut Marshal dan Arbuckle (2000) cit Andrianto, adanya pemutaran pada adonan es dengan menggunakan baling-baling menyebabkan udara dapat masuk pada adonan dan pendinginan menyebabkan pembekuan adonan sehingga udara yang terperangkap tidak dapat lepas. Jumlah total padatan yang tinggi mengandung banyak rantai pendek sehingga udara yang terperangkap dapat lebih banyak.

\section{G. Daya Leleh}

Pengamatan daya leleh dilakukan dengan cara mengamati rentang waktu yang dibutuhkan es krim sampai mencair sempurna. Pengamatan dilakukan pada suhu ruang. Daya leleh pada es krim bengkuang dengan penambahan ekstrak teh hijau dapat dilihat pada Tabel 8.

Tabel 8. Pengamatan Daya Leleh

\begin{tabular}{lc}
\hline \multicolumn{1}{c}{ Perlakuan } & Daya leleh (menit) \\
\hline D ( Konsentrasi ekstrak teh hijau 12,5\%) & 6,13 \\
E ( Konsentrasi ekstrak teh hijau 15\%) & 6,03 \\
B ( Konsentrasi ekstrak teh hijau 7,5\% ) & 6,03 \\
C ( Konsentrasi ekstrak teh hijau 10\% ) & 5,97 \\
A ( Konsentrasi ekstrak teh hijau 5\% ) & 5,90 \\
\hline KK=3,37\% & \\
\hline
\end{tabular}

Dari hasil pengamatan di atas didapatkan hasil daya leleh es krim berkisar antara 5,9 menit sampai 6,13 menit. Waktu daya leleh es krim tidak memiliki perbedaan yang jauh untuk setiap perlakuan. Hal ini disebabkan karena bahan padatan yang terkandung dalam es krim memiliki formulasi yang sama antara setiap perlakuannya. Menurut Widiantoko (2011), tingkat leleh dari suhu suatu es krim sangat mempengaruhi kualitas dari es krim itu sendiri. Es krim yang mudah meleleh ataupun yang terlalu keras tidak disukai oleh konsumen. Konsumen menginginkan es krim yang memiliki permukaan yang lembut namun tidak mudah meleleh. Es krim yang berkualitas tinggi tidak cepat meleleh saat dihidangkan pada suhu kamar $\left( \pm 27^{\circ} \mathrm{C}\right)$.

\section{H. Organoleptik}

Persentase kesukaan pada es krim bengkuang dengan penambahan ekstrak teh hijau dapat dilihat pada Tabel 9.

Tabel 9. Organoleptik

\begin{tabular}{lcccc}
\hline \multicolumn{1}{c}{ Perlakuan } & Warna & Aroma & Rasa & Tekstur \\
\hline A(Konsentrasi ekstrak teh hijau 5\%) & $45 \%$ & $40 \%$ & $55 \%$ & $40 \%$ \\
B(Konsentrasi ekstrak teh hijau 7,5\%) & $45 \%$ & $25 \%$ & $35 \%$ & $40 \%$ \\
C(Konsentrasi ekstrak teh hijau 10\%) & $35 \%$ & $30 \%$ & $45 \%$ & $45 \%$ \\
D(Konsentrasi ekstrak teh hijau 12,5\%) & $50 \%$ & $35 \%$ & $45 \%$ & $40 \%$ \\
E(Konsentrasi ekstrak teh hijau 15\%) & $50 \%$ & $30 \%$ & $30 \%$ & $45 \%$ \\
\hline
\end{tabular}


Pada Gambar 1 di bawah ini dapat dilihat gambaran hasil organoleptik terhadap es krim bengkuang dengan penambahan ekstrak teh hijau. Pada grafik terlihat, perlakuan A dengan penambahan ekstrak teh hijau konsentrasi 5\% memiliki tingkat kesukaan yang paling tinggi dibandingkan dengan perlakuan yang lain.

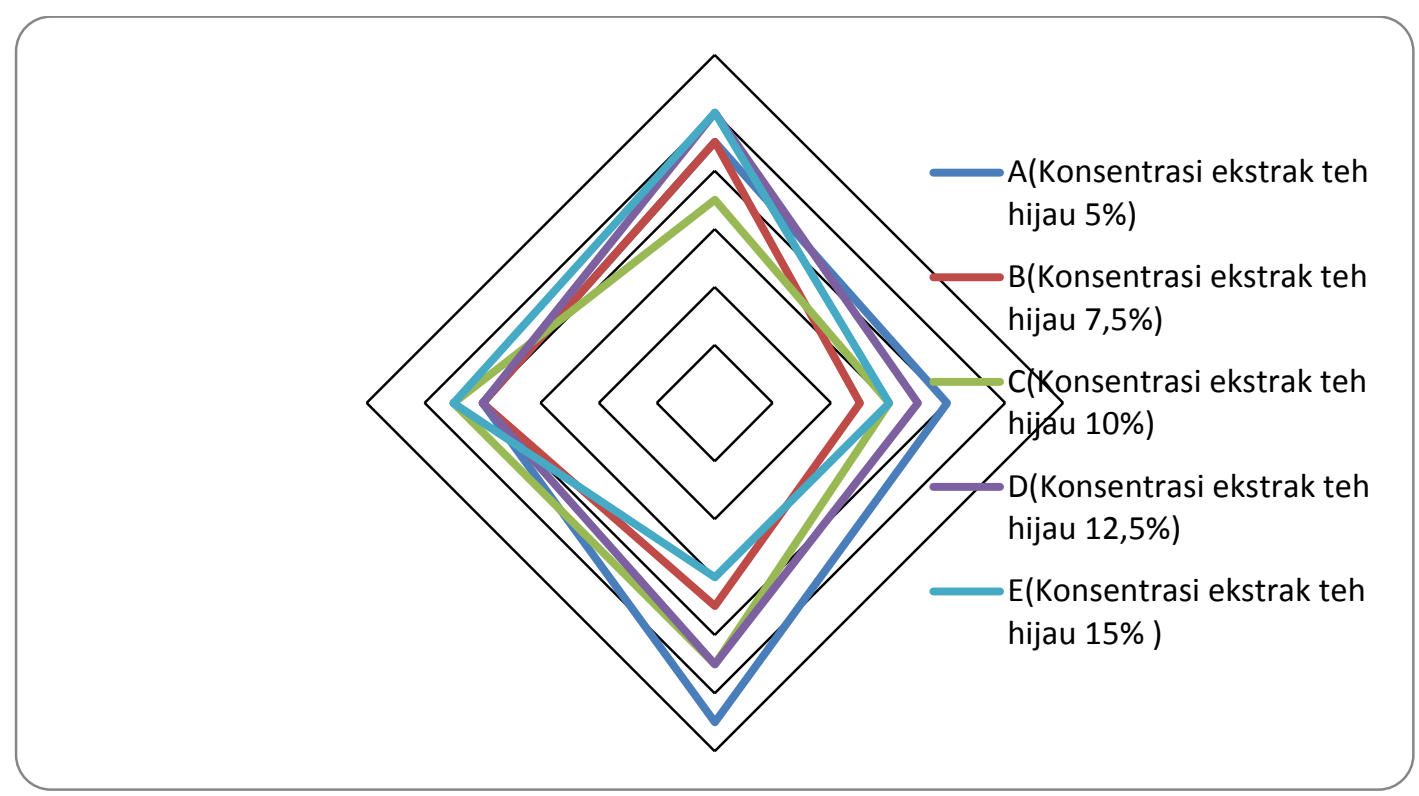

Gambar 1. Grafik Uji Organoleptik

\section{KESIMPULAN}

\section{Kesimpulan}

Berdasarkan penelitian yang telah dilakukan dapat diambil kesimpulan sebagai berikut:

1. penambahan ekstrak teh hijau terhadap es krim bengkuang tidak berbeda nyata terhadap kadar gula, total padatan terlarut, overrun, dan daya leleh. Namun berbeda sangat nyata terhadap kadar protein, kadar lemak dan aktivitas antioksidannya,

2. penambahan ekstrak teh hijau yang paling disukai panelis berdasarkan uji organoleptik adalah pada perlakuan A pada konsentrasi ekstrak teh hijau 5\% dengan persentase warna $45 \%$, aroma $40 \%$, rasa $55 \%$, dan tekstur $40 \%$. Kandungan kimia pada perlakuan A masih memenuhi standar SNI dengan persentase kadar gula 9,17\%, kadar protein $8,32 \%$, kadar lemak $8,36 \%$, total padatan terlarut $16,29 \%$, aktivitas antioksidan $35,38 \%$, overrun $27,38 \%$ dan daya leleh selama 5,90 menit.

\section{Saran}

Berdasarkan hasil penelitian yang telah dilakukan saran untuk penelitian selanjutnya, yaitu melakukan penelitian lanjutan mengenai umur simpan es krim bengkuang dengan penambahan ekstrak teh hijau, sehingga dapat mengetahui batasan waktu penyimpanannya dan uji mikrobiologinya.

\section{UCAPAN TERIMA KASIH}

Penulis mengucapkan terima kasih kepada bapak Dekan Fakultas Teknologi Pertanian Universitas Andalas yang telah membantu penelitian serta dukungan moril dan meteril sehingga dapat menyelesaikan penelitian ini dengan baik.

\section{DAFTAR PUSTAKA}

Anonimous. 2009. Umbi-umbian. Balai Informasi Pertanian Padang. Padang [BPS].Badan Pusat Statistik. 2012. Statistik Kecamatan Pauh. Dinas Pertanian. Padang 
[BSN].Badan Standarisasi Nasional Indonesia. 1995. SNI 01-3713-1995. Tentang Syarat Mutu Es Krim. http://sisni.bsn.go.id/index.php/sni/Sni/download/4132. Diakses tanggal 16 Maret 2017

Malaka, R., Maruddin, F. 2011. Penuntun Praktikum Ilmu dan Teknologi Pengolahan Susu. Jurusan Produksi Ternak Fakultas Peternakan. Universitas Hasanuddin. Makassar.

Marshall, R.T dan W.S.Arbuckle. 2000. Ice Cream. $5^{\text {th }}$ Edition. Aspen Publisher, Irc., Gaithersburg, Maryland.

Muharlien. 2010. Meningkatkan Kualitas Telur Melalui Penambahan Teh Hijau Dalam Pakan Ayam Petelur. Jurnal Ilmu dan Teknologi Hasil Ternak, Februari 2010, Vol. 5, No. 1 Hal 32-37 Jurusan Produksi Ternak Fakultas Peternakan. Universitas Brawijaya. Malang.

Rohdiana, D. 2009. Teh Ini Menyehatkan (Telaah Ilmiah Populer). Alfabeta: Bandung. Cetakan I.

Rossi, A. 2010. 1001 Teh (Dari Asal-usul, Tradisi, Khasiat, Hingga Racikan Teh). Andi Offset. Yogyakarta.

Syafutri; M. Indriyani dan Eka Lidiasari 2012. Karakteristik Es Krim Hasil Modifikasi Dengan Formulasi Bubur Timun Suri (Cucumis melo, L) dan Sari Kedelai. Jurnal Teknolologi dan Industri Pangan Th. 2012,Vol. XXIII No. 1 hal 17-22. Perhimpunan Ahli Teknologi Pangan Indonesia, Bogor.

Widiantoko, R.K. 2011. Es Krim. http://lordbroken.wordpress.com/2011/04/10. [Diakses tgl 03 Oktober 2017] 